\title{
Effects of Laser Offset and Hybrid Welding on Microstructure and IMC in Fe-Al Dissimilar Welding
}

\author{
Giuseppe Casalino ${ }^{1, *}$ (D), Paola Leo ${ }^{2}$, Michelangelo Mortello ${ }^{3}$ (D), Patrizia Perulli ${ }^{1}$ \\ and Alessandra Varone 4 \\ 1 DMMM Politecnico di Bari, 70124 Bari, Italy; patrizia.perulli@poliba.it \\ 2 Dipartimento di Ingegneria dell'Innovazione, Universita del Salento, 73100 Lecce, Italy; \\ paola.leo@unisalento.it \\ 3 Welding Engineering Research Centre, Building 46, Cranfield University, Bedfordshire MK43 0AL, UK; \\ M.Mortello@cranfield.ac.uk \\ 4 Department of Industrial Engineering, University of Rome “Tor Vergata", Via del Politecnico 1, 00133 Rome, \\ Italy; Alessandra.varone@uniroma2.it \\ * Correspondence: Giuseppe.Casalino@poliba.it; Tel.: +39-080-5962753
}

Received: 27 June 2017; Accepted: 20 July 2017; Published: 25 July 2017

\begin{abstract}
Welding between Fe and $\mathrm{Al}$ alloys is difficult because of a significant difference in thermal properties and poor mutual solid-state solubility. This affects the weld microstructure and causes the formation of brittle intermetallic compounds (IMCs). The present study aims to explore the weld microstructure and those compounds over two different technologies: the laser offset welding and the hybrid laser-MIG (Metal inert gas) welding. The former consists of focusing the laser beam on the top surface of one of the two plates at a certain distance (offset) from the interfaces. Such a method minimizes the interaction between elevated temperature liquid phases. The latter combines the laser with a MIG/MAG arc, which helps in bridging the gap and stabilizing the weld pool. AISI 316 stainless steel and AA5754 aluminum alloy were welded together in butt configuration. The microstructure was characterized and the microhardness was measured. The energy dispersive spectroscopy/X-ray Diffraction (EDS/XRD) analysis revealed the composition of the intermetallic compounds. Laser offset welding significantly reduced the content of cracks and promoted a narrower intermetallic layer.
\end{abstract}

Keywords: laser offset welding; hybrid welding; microstructure; intermetallic layer

\section{Introduction}

Lightweight metals and their alloys are increasingly used as efficient structural materials. The reduction of the overall weight of a vehicle decreases the fuel consumption and carbon emissions. This accomplishment is highly requested for automotive, aerospace, and shipbuilding industries [1]. Aluminum is one of the most popularly used lightweight metal, thanks to its low density, good corrosion resistance, and excellent workability [2]. Replacing conventional steel components with hybrid dissimilar Al-Fe assemblies is beneficial to improve flexibility, vehicle energy efficiency, and cut down the manufacturing costs.

Achieving a reliable fusion welded joint between $\mathrm{Al}$ and $\mathrm{Fe}$ alloys is challenging, due to the low mutual solid solubility and the large difference in thermal properties. This includes the melting points $\left(660\right.$ versus $\left.1535^{\circ} \mathrm{C}\right)$, the thermal conductivities $\left(238\right.$ versus $\left.77.5 \mathrm{~W} \cdot \mathrm{m}^{-1} \cdot \mathrm{K}^{-1}\right)$, and thermal expansion coefficients $\left(23.5 \times 10^{-6}\right.$ and $\left.11.76 \times 10^{-6} / \mathrm{K}\right)$. Additionally, the nearly-zero solid state solubility of $\mathrm{Al}$ in $\mathrm{Fe}$, and the zero solubility of $\mathrm{Fe}$ in $\mathrm{Al}$ result in the formation of brittle intermetallic compounds (IMCs), which deteriorate the mechanical properties and form cracks [3,4]. According to Fe-Al phase diagram [5], IMCs include Fe-rich compounds ( $\mathrm{FeAl}$ and $\mathrm{Fe} 3 \mathrm{Al}$ ) and $\mathrm{Al}$-rich compounds $\left(\mathrm{FeAl}_{2}, \mathrm{Fe}_{2} \mathrm{Al}_{5}\right.$, 
and $\mathrm{FeAl}_{3}$ ). The crystalline arrangement suffers from low mobility of dislocations and slip systems. Thus, the formation of Al-Fe phases plays a key role in achieving an effectual connection between the two metals, but the excessive formation of IMCs results in brittleness and degrades the strength of the joint [3]. Furthermore, a "strength-mismatch effect" was observed in between two different steels [6,7]. The mismatch characteristic of the weld is to ensure that the welded joint withstands in-service constraints and provides good weld quality [8].

Some authors demonstrated the feasibility of using friction stir welding (FSW) for producing tough $\mathrm{Fe}-\mathrm{Al}$ welds [9-14]. However, laser welding is potentially a more attractive technology for dissimilar joining, mostly in automotive and aerospace applications, thanks to its high versatility, precision, and productivity. It exhibits locally focused energy delivery in a small spot size and high process speed, which provides a smaller weld pool, higher cooling rate, and a shorter reaction time for IMC growth.

Since the thermal gradients and the reaction time determines the width of the IMC zone, one of the main concerns of researchers is the investigation of the welding conditions which minimize the growth of brittle phases. The control of temperature at the interfaces is fundamental for the right growth of the IMC layer. Meco et al., analyzed the transient thermal cycle of the laser-material interactions' fundamental parameters. The growth and distribution of IMCs correlated with the thermal cycle [15]. Qin et al., developed a finite element model to investigate the temperature fields in the weld zone during laser-arc welding. They found that the distribution of the temperature and the reaction time is not uniform along the thickness, which leads to non-uniform IMC layers [16]. Gao et al., proved that the non-uniformity in the thickness and the irregular shape of the interface increase with the heat input [17]. Recent studies showed that the intermetallic bond is altered by post-welding heat treating the joint [18].

Apart from the extension of the reaction area, the properties of IMCs are hugely responsible for the weld resistance. Chen et al., proved that the interposition of a Ni-foil interlayer improves the toughness, even if additional IMCs form [19]. The composition of the filler material is highly influential on the seam properties. Mathieu et al., adopted a hot wire to improve the adhesion of the filler material at the interfaces and demonstrated how the welding conditions are responsible for the zone in which the fracture occurs [20]. Dharmendra et al., used a low-melting point Zn-15Al filler alloy, which exhibited good wetting properties [21]. Song et al., explored how the dynamics of Al-Si filler material at liquid state affect the morphology of the weld [22]. Finally, the interposition of Al-Si filler material during resistance spot welding was used in overlap configuration [23].

The combination between laser and arc into a hybrid process improves the process robustness and stability, enables deeper penetration, provides compensation for the geometrical defects and misalignments, and ensures tolerance in joint fit-up and wider control of weld metallurgy [24,25]. Among process parameters, the power distribution has proved to have a deep impact on the weld quality for similar and dissimilar welding [26-28].

The laser offset welding (LOW) was used to weld dissimilar assemblies. The beam focused on the top surface of one of the two materials to promote a liquid-solid interaction, which produces the bond. Such a method limited the growth of an IMC layer and promoted the diffusion through the liquid-solid boundary, without mixing liquid phases at elevated temperature. This approach was used for several dissimilar welds [29-33]. Pardal et al., reduced the mutual inter-diffusion and the thickness of IMCs by carrying out the dissimilar Al-Fe joining process in conduction mode. Aluminum melted but the steel did not, so a liquid-solid interface formed in the volume of the weld [34].

In this work, a comparative study between laser offset and hybrid laser welding of AA5754 and 316 stainless steel is presented. The morphology of the weld was revealed by visual inspection. The microstructure and interlayer were characterized by optical and electron microscopy. The phases and their distribution were identified by microhardness, which was compared with data available in the literature. The EDS/XRD analysis revealed the composition of the intermetallic compounds. 
The overall result showed an effective bond between aluminum and steel, if complex interactions are controlled and limited to a small amount.

\section{Experimental Procedures}

\subsection{Material Properties and Weld Configuration}

In this study, the butt weld geometry was used for testing the weldability of a dissimilar Al-Fe weld. The dimensions of the sheets (length $\times$ width $\times$ thickness) were $100 \times 50 \times 3 \mathrm{~mm}^{3}$ for the aluminum sheet and $100 \times 50 \times 2 \mathrm{~mm}^{3}$ for the steel one. The difference in plate thickness was chosen to improve the wettability of aluminum on the steel. $0.8 \mathrm{~mm}$ diameter AISI 316 steel filler wire was used for the hybrid laser-arc process. Tables 1 and 2 show the characteristics of the as-received materials.

Table 1. Chemical composition of the as-received materials (wt \%).

\begin{tabular}{ccccccccccccc}
\hline Metal & C & Al & Cr & Mn & Mo & Mg & Ni & Ti & P & S & Si & Fe \\
\hline AISI 316 & 0.08 & - & 18 & 2 & 3 & - & 14 & - & 0.045 & 0.03 & 1 & balance \\
AA5754 & - & balance & 0.30 & 0.50 & - & 3.6 & - & 0.15 & - & - & 0.40 & 0.40 \\
\hline
\end{tabular}

Table 2. Properties of the as-received materials: ultimate tensile strength (UTS), yield stress (YS), Young module (E), elongation to fracture $\%(A \%)$, Vickers microhardness (HV), thermal conductivity $(\mathrm{K})$, Liquidus Temperature $\left(\mathrm{T}_{\mathrm{L}}\right)$, density $(\rho)$, specific heat capacity $(\mathrm{c})$.

\begin{tabular}{cccccccccc}
\hline Metal & UTS (MPa) & YS (MPa) & E (GPa) & $\mathbf{A} \%$ & HV & $\mathbf{K ~ ( W / ( m \cdot K ) )}$ & $\mathbf{T}_{\mathbf{L}}\left({ }^{\circ} \mathbf{C}\right)$ & $\boldsymbol{\rho}\left(\mathbf{g} / \mathbf{c m}^{3}\right)$ & $\mathbf{c}\left(\mathbf{J} /\left(\mathbf{g} \cdot{ }^{\circ} \mathbf{C}\right)\right)$ \\
\hline AISI 316 & 580 & 290 & 193 & 50 & 178 & 16.3 & 1400 & 8 & 0.5 \\
AA5754 & 230 & 80 & 68 & 17 & 62 & 147 & 600 & 2.66 & 0.9 \\
\hline
\end{tabular}

\subsection{The Welding Procedures}

The welds were produced using two different technologies: the laser offset welding (LOW) and the hybrid laser-MIG welding. When using LOW, the laser source was focused on the steel side at a certain distance (offset) from the bimetal interface (Figure 1). In this investigation, the off-set value was about $1 \mathrm{~mm}$ from the laser beam axis. The keyhole moved along a linear path, parallel to the interface. The heat transferred to the aluminum side through the steel heat affected zone, as shown in Figure 2. The thermal energy spreading from the keyhole caused the fusion of the aluminum. In this way, the steel fusion zone (FZ) separated the steel molten pool from the aluminum-fused zone, which avoided the excessive growth of the IMC layer.

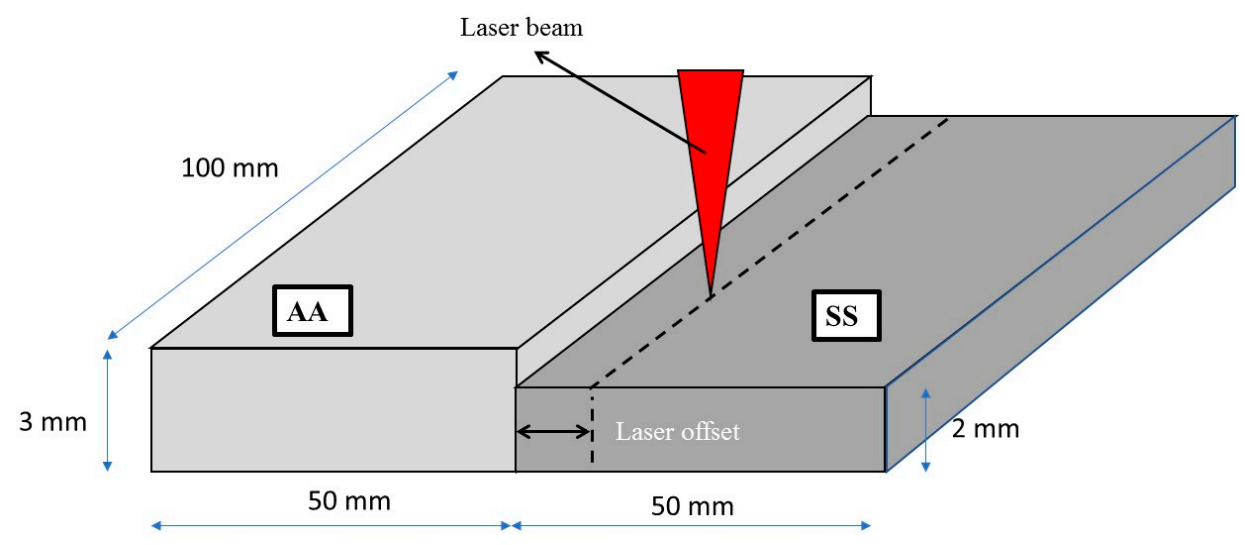

Figure 1. Schematic illustration of the laser offset welding (LOW) technique procedure.

Focusing the beam on the steel plate instead of the aluminum one is advantageous because it enables better process control. The stability of the keyhole depends on the balance of different force 
contributions, which include recoil pressure of the vaporized material, pressure inside the cavity, surface tension, pressure, and weight of molten metal. If the process is not largely robust and stable, small deviations of the process conditions from the design point, might compromise the stability of the keyhole, leading to collapse and uncontrolled liquid and thermal flows. Aluminum plate is highly reflective to beam radiation and exhibits high diffusivity, making it difficult to keep the process stable during the weld. Thus, even if the melting point of aluminum is lower than steel one, the process has been conducted by focusing the beam on the steel side, in opposition to brazing principles.

On the other hand, during laser-MIG hybrid welding (Figure 3) the laser-arc coupled source was directed straight to the weld centerline and it moved along that line. After preliminary trials, the wire was positioned at a $1 \mathrm{~mm}$ distance from the laser focus. The laser and arc combination promotes a stable wire deposition, without any spatter generation.

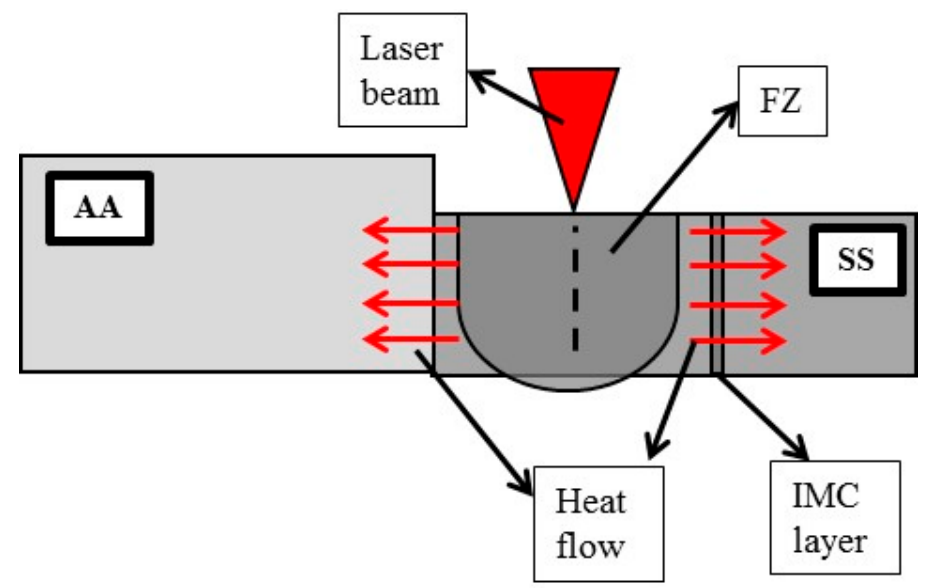

Figure 2. Schematic drawing for describing the joining mechanism by the LOW technique.

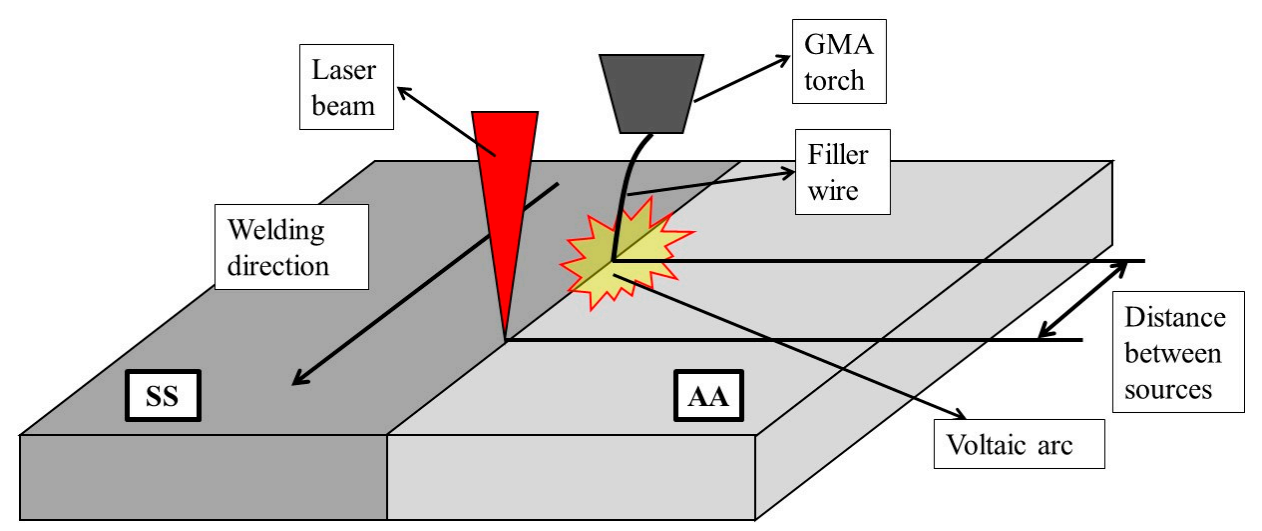

Figure 3. Schematic illustration of laser-MIG (Metal inert gas) technique procedure.

Before welding, the sheets were machined at low milling speed, which reduced the thermal contact resistance. Dust and contaminants were removed by cleaning with acetone.

\subsection{Set-Up of the Welding Systems}

Two different laser systems were used to perform the trials:

For laser offset welding, it consisted of a 6-axis robot, a stationary shielding box system and a workbench equipped with clamps and supporting table (Figure 4). A YLS-4000 Yb-doped fiber laser with a wavelength of $1070 \mathrm{~nm}$ and a maximum power of $4 \mathrm{~kW}$ (IPG Laser GmbH, Barbuch, Germany) was used in continuous wave regime. The fiber had $200 \mu \mathrm{m}$ diameter, while the optics (focal lens and 
collimator) provided a magnification factor of 2 , resulting in roughly a $0.4 \mathrm{~mm}$ beam diameter, which was calculated by the $1 / \mathrm{e}^{2}$ width method, near-Gaussian distribution.

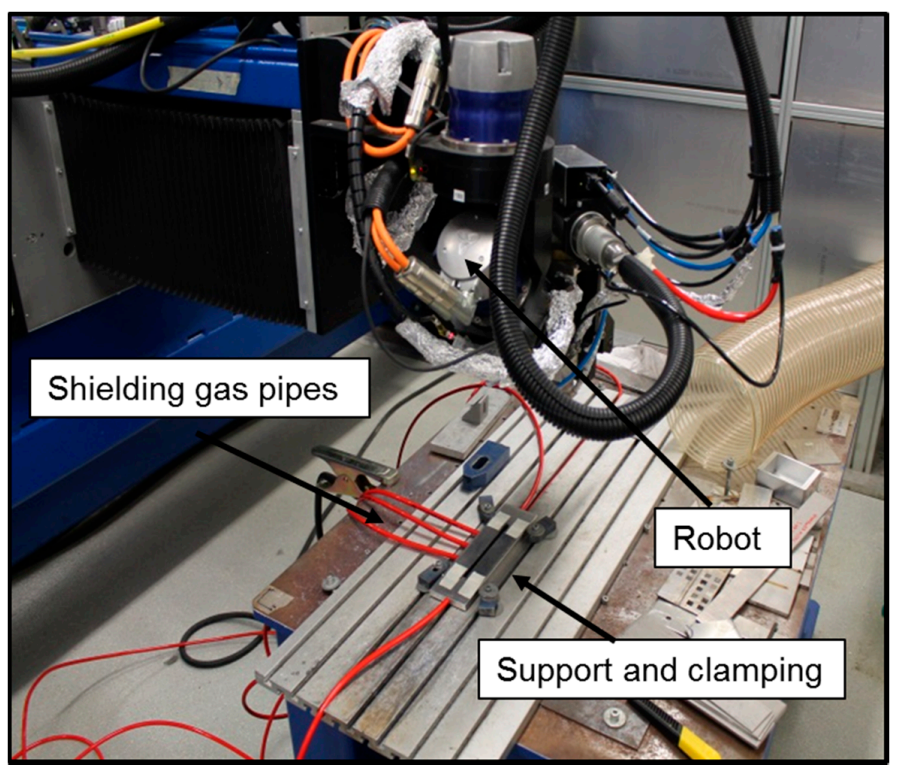

Figure 4. Overall experimental set-up.

For hybrid laser welding, a $\mathrm{CO}_{2}$ laser (Rofin, Hamburg, Germany) whose maximal power was $3 \mathrm{~kW}$ was used operating in continuous wave mode. The focusing mirror was parabolic and it had a $160 \mathrm{~mm}$ radius. A laser beam coaxial argon shielding gas is used, which is advantageous for arc stability. Figure 5 shows the laser-MIG coupling.

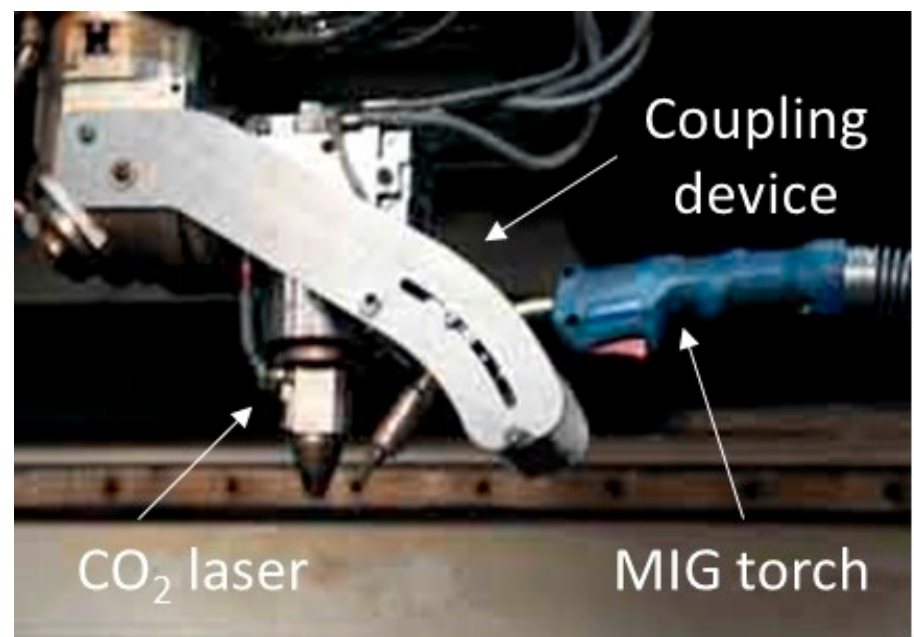

Figure 5. Laser-MIG coupling.

\subsection{Process Parameters}

Preliminary bead-on-plate tests were conducted to find out the process parameters that enabled the weld formation. The process parameters and their levels are summarized in Table 3. The overall power used for the hybrid welding (laser power + MIG power) was $3420 \mathrm{~W}$ (versus $2500 \mathrm{~W}$ used for laser welding). 
Table 3. Experimental plan.

\begin{tabular}{cccccc}
\hline & $\begin{array}{c}\text { Laser Power } \\
\mathbf{( k W )}\end{array}$ & $\begin{array}{c}\text { Welding } \\
\text { Speed (m/min) }\end{array}$ & $\begin{array}{c}\text { Wire Feed } \\
\text { Speed (m/min) }\end{array}$ & Current (A) & Voltage (V) \\
\hline Laser Offset Welding & 2.5 & 2 & - & - & - \\
Hybrid Laser-MIG Welding & 3.42 & 2 & 1.2 & 80 & 24 \\
\hline
\end{tabular}

\subsection{Metallographic Analysis and Mechanical Testing}

Weld cross sections were cold mounted and then they were grinded and mechanically polished using a variable speed. The microstructure was analyzed by Epiphot 200 Optical Microscope (OM, Nikon, Tokyo, Japan) and EVO scanning electron microscope (SEM, Zeiss, Oberkochen, Germany), equipped with an energy-dispersive X-ray spectrometer (EDS, Bruker AXS Inc, Madison, WI, USA). The samples were prepared by a standard metallographic procedure, which involved etching with the following reagents:

- Keller's solution (1 mL HF, $1.5 \mathrm{~mL} \mathrm{HCl}, 2.5 \mathrm{~mL} \mathrm{HNO}_{3}$, and $95 \mathrm{~mL} \mathrm{H}_{2} \mathrm{O}$ ) for aluminum microstructure.

- Vilella's solution (1 g picric acid, $5 \mathrm{~mL} \mathrm{HCl}, 100 \mathrm{~mL}$ ethanol) for steel microstructure.

Vickers micro-hardness tests with a load of $0.1 \mathrm{Kg}$ (AffriWiky 200JS2) were carried out to estimate local mechanical properties of welds and intermetallic phases created at the steel/aluminum interface.

$\mathrm{X}$-ray diffraction measurements were carried out on a Rigaku diffractometer with $\mathrm{CuK} \alpha$ radiation $(\lambda=0.154 \mathrm{~nm})$. The $X$-ray diffraction data were collected at a scanning rate of $0.02^{\circ} / \mathrm{s}$ in $2 \theta$ ranging from $20^{\circ}$ to $100^{\circ}$ with count time $1.0 \mathrm{~s}$ in the fusion zone of both the aluminum and steel sheet. In the thin intermetallic layer, the X-ray diffraction data were collected at a scanning rate of $0.02^{\circ} / \mathrm{s}$ in $2 \theta$ ranging from $20^{\circ}$ to $55^{\circ}$ with count time $6.0 \mathrm{~s}$.

\section{Base Material Characterization}

AA5754 Al-Mg alloy was supplied in annealed and recrystallized state. The optical micrograph (Figure 6) shows the aluminum matrix (solid solution phase) together with a series of intermetallic precipitates. Based on previous works [35-37], it can be concluded that the acicular shape, light gray particles are $(\mathrm{Fe}, \mathrm{Mn}) \mathrm{Al}_{6}$ (Figure 6), while the rounded shape dark gray particles consist of fragile $(\mathrm{Fe}, \mathrm{Mn})_{3} \mathrm{SiAl}_{12}$ (Figure 6). The larger black particles are $\mathrm{Mg}_{2} \mathrm{Si}$ (Figure 6), while the smaller ones are $\mathrm{Mg}_{2} \mathrm{Al}_{3}[35,36]$.

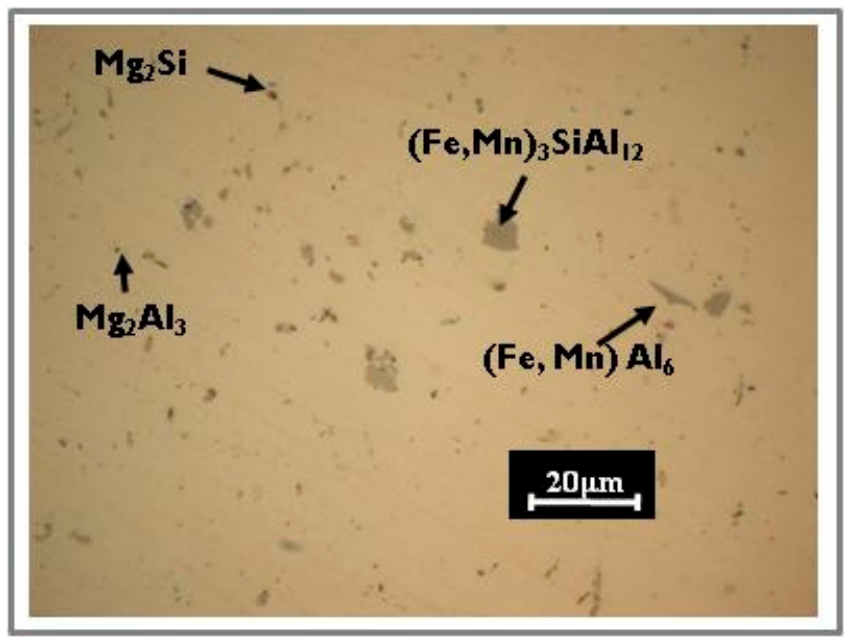

Figure 6. Optical micrograph of AA5754 base material. Light gray acicular shape particles ( $\mathrm{Fe}, \mathrm{Mn}) \mathrm{Al}_{6}$, rounded shape dark gray particles $(\mathrm{Fe}, \mathrm{Mn})_{3} \mathrm{SiAl}_{12}$, black particles $\mathrm{Mg}_{2} \mathrm{Si}$, the smaller ones are $\mathrm{Mg}_{2} \mathrm{Al}_{3}$. 
The microstructure of the 316L base material is presented in Figure 7, showing an equiaxed, twinned microstructure. Annealing twins (induced by heat treatment) and deformation twins are typical of austenitic stainless steels, which are characterized by low stacking fault energy (SFE). The low SFE austenitic steel induces a planar array of dislocations during the deformation, promoting deformation twinning. The twin boundaries are barriers to the dislocation slipping, which increases the strain-hardening rate [36].

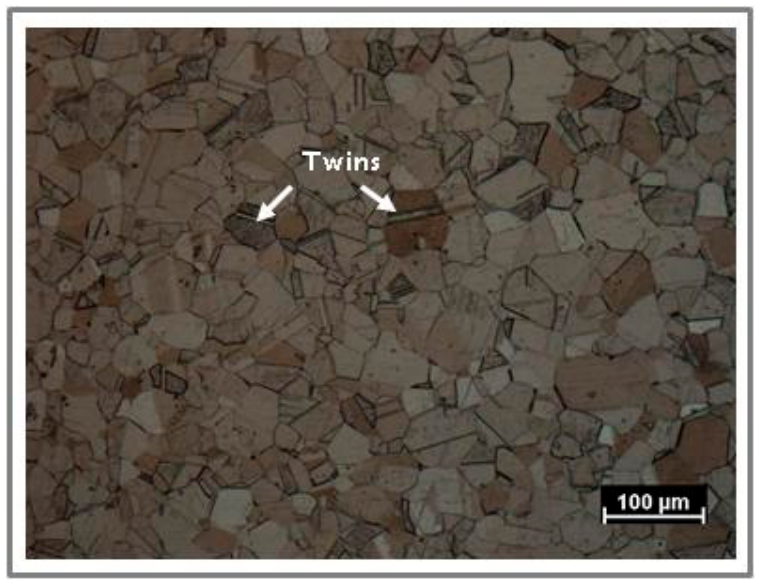

Figure 7. Polarized light micrograph base material of 316L stainless steel showing austenitic structure with twins.

\section{Laser Off-Set Welding Results}

The morphology of the cross section of the joint produced by laser offset welding is shown in Figure 8. At this stage, the sample was weakly etched, which permitted focusing the analysis on the bead shape. Detailed microstructural features were resolved later.

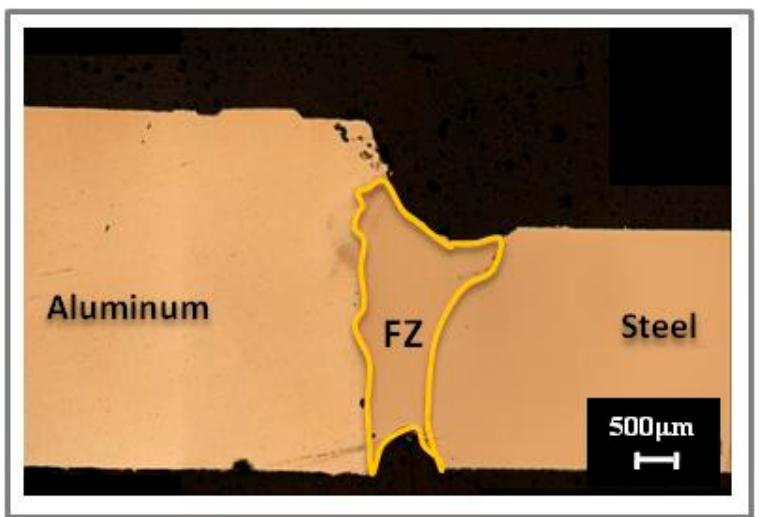

Figure 8. Optical macrograph of cross section obtained by LOW technique.

Full penetration was achieved. The undercut at the top surface was prevented, while the bottom part of the weld exhibited a slight sagging. Such a geometric defect mainly derived from the contraction of liquid walls during the solidification and recoil pressure inside the keyhole, which made the molten material fill the volume of the cavity as the source advanced.

Figure 9a,b shows the IMC layer formed by the Fe-Al reaction. The interface appeared curvilinear and Fe-based isles were distributed non-uniformly within the thickness. The low thermal input promoted a slight interaction between liquid-state materials. A magnification of zone A is shown in Figure 9b. 


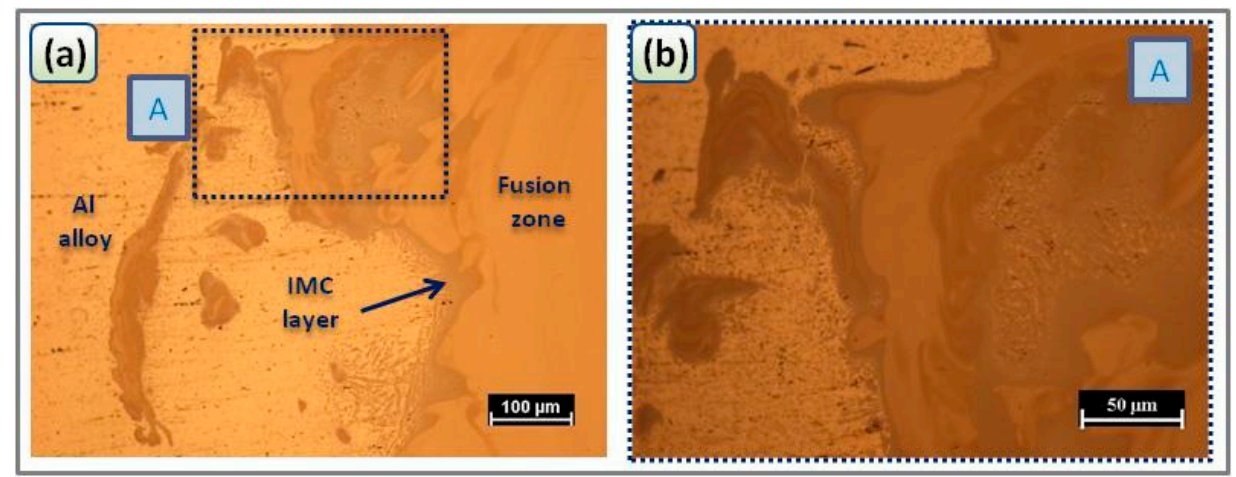

Figure 9. Optical micrographs of the intermetallic compounds (IMC) layer of the joint at: (a) $200 \times$; (b) high-magnification image of area $\mathrm{A}$ in (a) at $500 \times$.

The IMCs formation is diffusion controlled and dependent on time and thermal cycles. The key challenge in joining dissimilar materials is the accurate control of the fusion behaviour and the mixing of interfacing materials. Focusing the beam on the steel side confined the interaction between liquid phases into a narrow area. The keyhole was kept stable within the steel side, without affecting the interface zone. Firstly, the aluminum side was not subjected to the direct exposition to laser emission. Therefore, neither vaporization of alloying elements, nor liquid viscous flows towards the interface was observed. Secondly, since the beam was focused far enough from the interface, large liquid viscous forces were prevented. Thus, the growth of IMCs was limited and liquid flows were confined by the interface boundary, without creating any excessively large mixed zone. Laser offset welding significantly reduced the content of cracks and promoted a narrower intermetallic layer, which was limited to roughly $6 \mu \mathrm{m}$. (Figure 10). Moreover, the rapid process speed lead to a high cooling rate, enabling a narrower fusion zone [37]. Consequently, the shorter interaction time and narrower fusion area promoted a thinner IMC layer. Such a result is hugely beneficial for the joint strength [30].

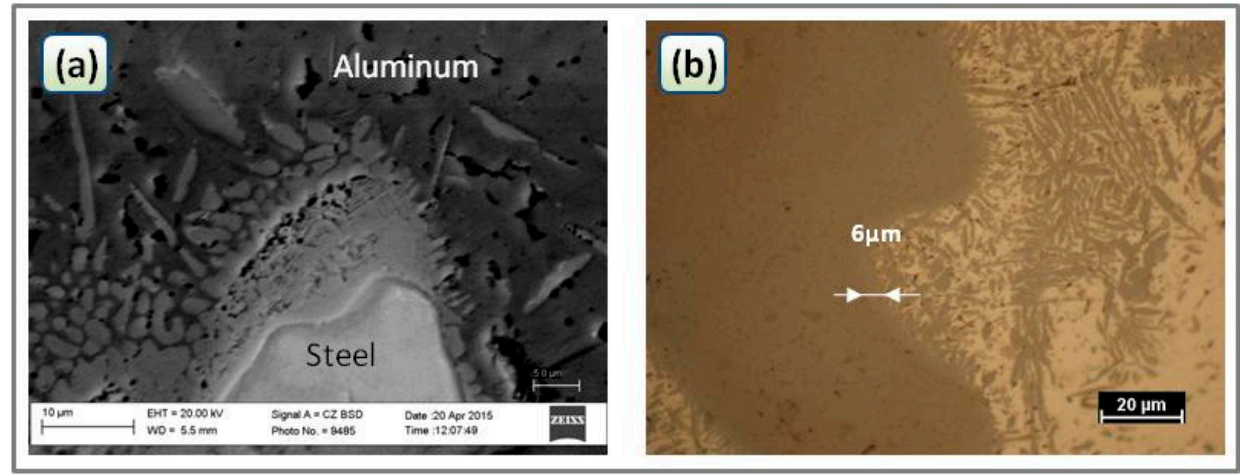

Figure 10. (a) Scanning electron microscopy (SEM) and (b) optical micrographs showing the IMC layer.

Firstly, the composition of the IMC layer was analyzed by the energy dispersive spectroscopy (EDS) analysis during the SEM investigation (Figures 11 and 12). Figure 11 shows the maps of elements at the interface (Figure 11b,c), meanwhile Table 4 gives the composition (at \%) of $\mathrm{Fe}$ and $\mathrm{Al}$ in the points P1 (layer_1) and P2 (layer_2), which were located in Figure 12. The analysis of the maps in Figure 11b,c indicated that the light gray areas in Figure 11a contained mainly iron and aluminum, while the fused zones contained iron and aluminum together with their alloy elements. Particularly, the effect of the diffusion of $\mathrm{Al}$ alloy elements towards the steel fusion zone and $\mathrm{Fe}$ alloy towards the aluminum side can be observed. The local chemical analysis in Figure 12 revealed that the chemical composition of the IMC layer in the investigated points could be $\mathrm{Fe}_{2} \mathrm{Al}_{5}$ - or $\mathrm{FeAl}_{2}$-type according to Fe-Al phase diagram [5]. 


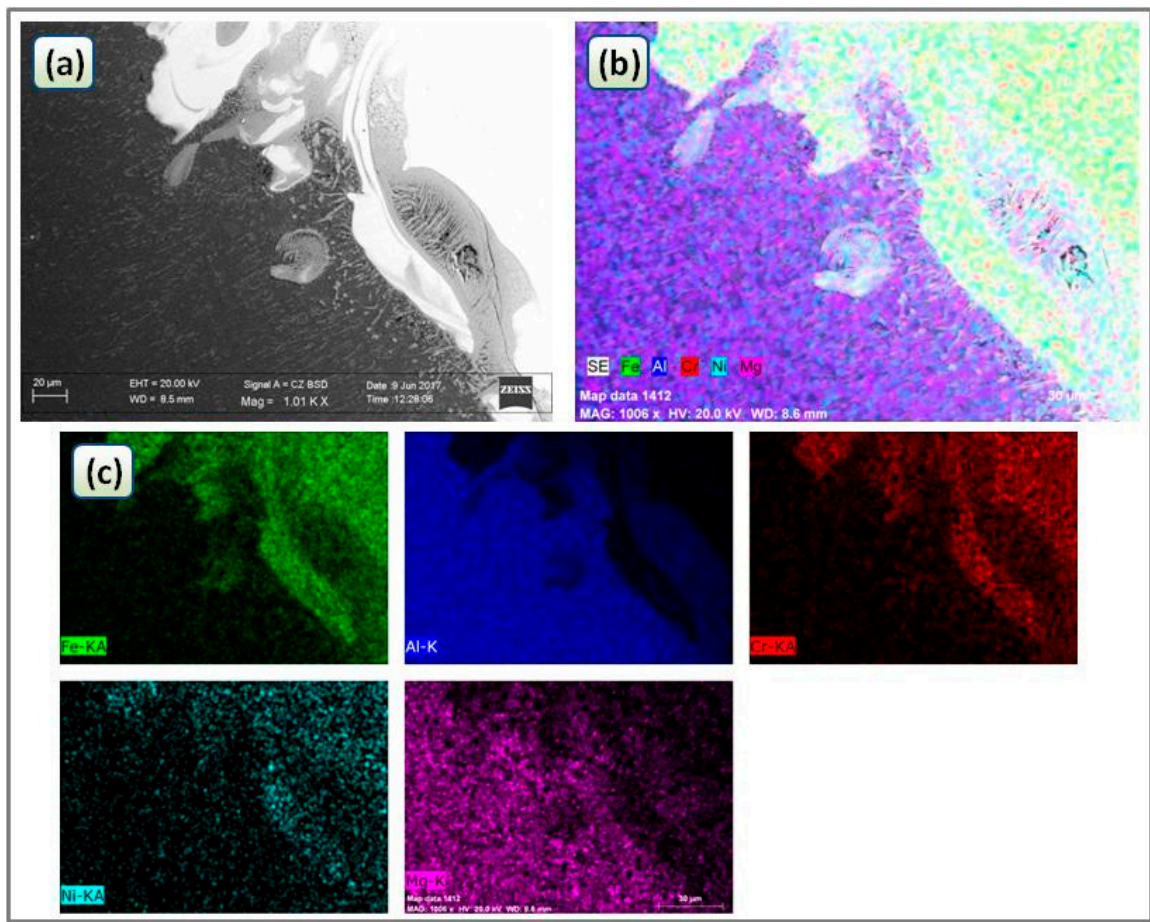

Figure 11. (a) SEM micrograph (Back scattered electrons) showing the IMC layer (b) alloy elements mapping and (c) maps of single elements at the joint interface.

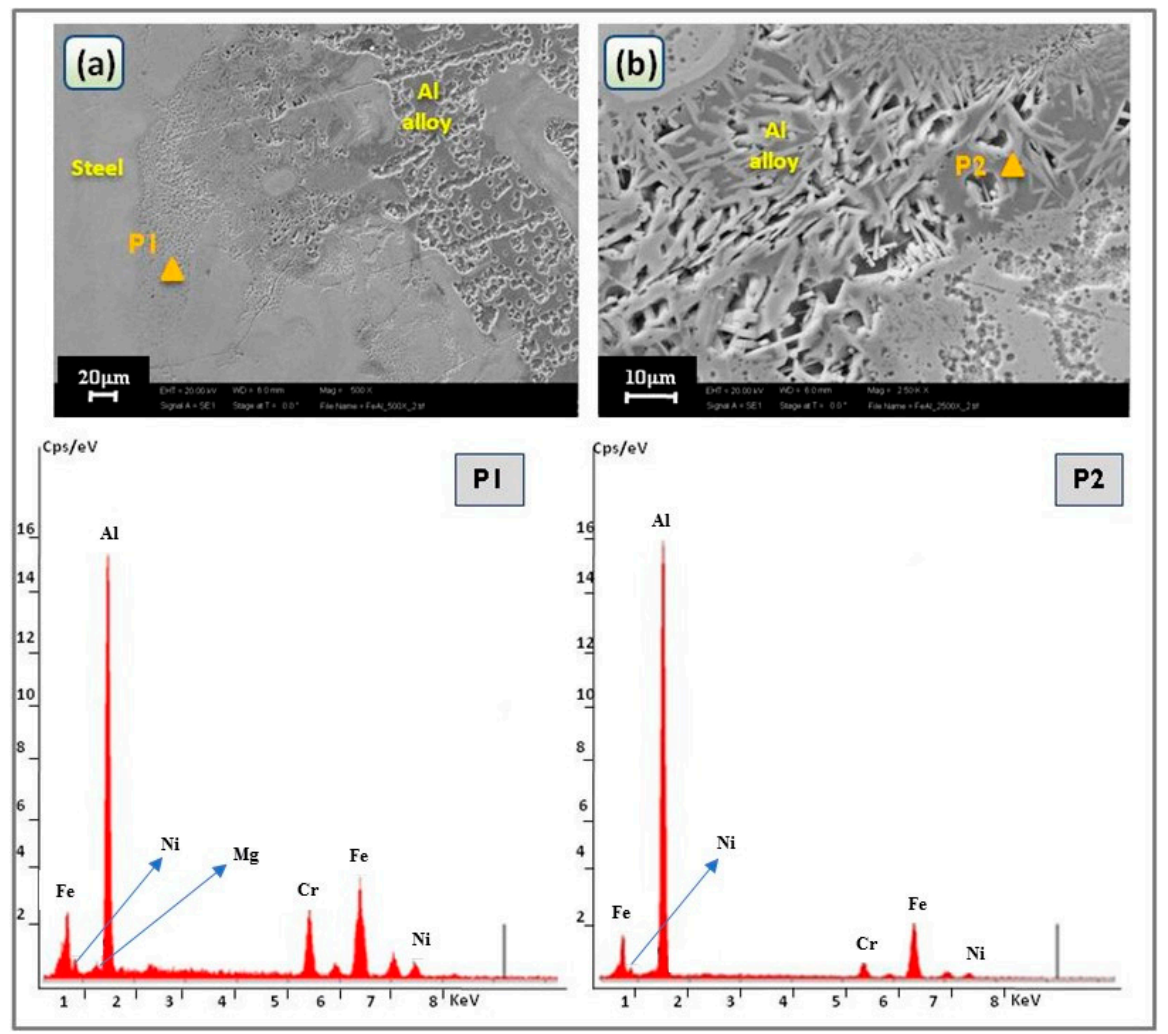

Figure 12. SEM micrographs of the IMC zone of the cross section with energy dispersive spectroscopy (EDS) analysis results in the highlighted points P1, P2 at (a) $5000 \times$ and (b) $10,000 \times$ magnifications. 
Table 4. Chemical compositions at different points near aluminum/fusion zone interface (at \%).

\begin{tabular}{cccccc}
\hline Point No. & Al & Fe & Cr & Ni & Mg \\
\hline P1 & 63.9 & 26.2 & 5.8 & 3.3 & 0.8 \\
P2 & 71.37 & 23.43 & 3.6 & 1.6 & - \\
\hline
\end{tabular}

As shown in the $\mathrm{Fe}-\mathrm{Al}$ binary phase diagram [5], primarily five types of $\mathrm{Fe}-\mathrm{Al} \mathrm{IMCs}$ (i.e., $\mathrm{Fe}_{3} \mathrm{Al}$, $\mathrm{FeAl}, \mathrm{FeAl}_{2}, \mathrm{Fe}_{2} \mathrm{Al}_{5}$, and $\mathrm{FeAl}_{3}$ phases) are produced during the $\mathrm{Fe} / \mathrm{Al}$ reaction process [38]. The sequence of the formation of $\mathrm{Fe}-\mathrm{Al} \mathrm{IMCs}$ based on the thermodynamic data of the free energy indicates that $\Delta \mathrm{G}^{\circ}\left(\mathrm{Fe}_{2} \mathrm{Al}_{5}\right)<\Delta \mathrm{G}^{\circ}\left(\mathrm{FeAl}_{3}\right)<\Delta \mathrm{G}^{\circ}\left(\mathrm{FeAl}_{2}\right)<\Delta \mathrm{G}^{\circ}(\mathrm{FeAl})<0<\Delta \mathrm{G}^{\circ}\left(\mathrm{Fe}_{3} \mathrm{Al}\right)$ [38-41], suggesting that the first phase to be formed is $\mathrm{Fe}_{2} \mathrm{Al}_{5}$.

The nature of the IMCs compounds in the joint was assessed by XRD analysis (Figure 13a). Because the stoichiometry of the $\mathrm{Fe}_{2} \mathrm{Al}_{5}, \mathrm{FeAl}_{3}$, and $\mathrm{FeAl}_{2}$ compounds is very close each other, it is not possible to distinguish them by EDS chemical analysis. Particularly, in the intermetallic area, a precision X-ray diffraction analysis was employed to try and identify the compounds in the thinner intermetallic layer. Both the fusion zone of aluminum and steel was analyzed by XRD (Figure 13b,c). In the steel fusion zone were detected the diffraction peaks of Aluminum and Iron, meanwhile in the Al zone only the aluminum peak were detected. The XRD spectrum in the intermetallic zone identified only the $\mathrm{FeAl}_{2}$ compound together with the $\mathrm{Al}$ matrix, while no trace of more stable compounds was found. The reason could be the low amount of the more stable compounds (i.e., $\mathrm{Fe}_{2} \mathrm{Al}_{5}$ ). In fact, the joint solidification is a non-equilibrium process, which is characterized by high welding speed $(2 \mathrm{~m} / \mathrm{min})$ and cooling rate. Therefore, the compounds' crystallization could be not strictly in accordance with thermodynamic condition. So, if thermodynamically more stable compounds (such as $\mathrm{Fe}_{2} \mathrm{Al}_{5}$ ), being diffusion controlled, do not have enough time to grow during the cooling of the joint, some other less stable compounds (such as $\mathrm{FeAl}_{2}$ ) could nucleate and grow preferentially [42]. Vickers micro-hardness measurements on the intermetallic interface layer (Figure 14) were in accordance with the values reported in the literatures for $\mathrm{FeAl}$ or $\mathrm{Fe}_{2} \mathrm{Al}_{5}$ (Figure 14a) compounds [1,3]. In such a case, the values of hardness could be underestimated because of the Al matrix (Figure 14b).

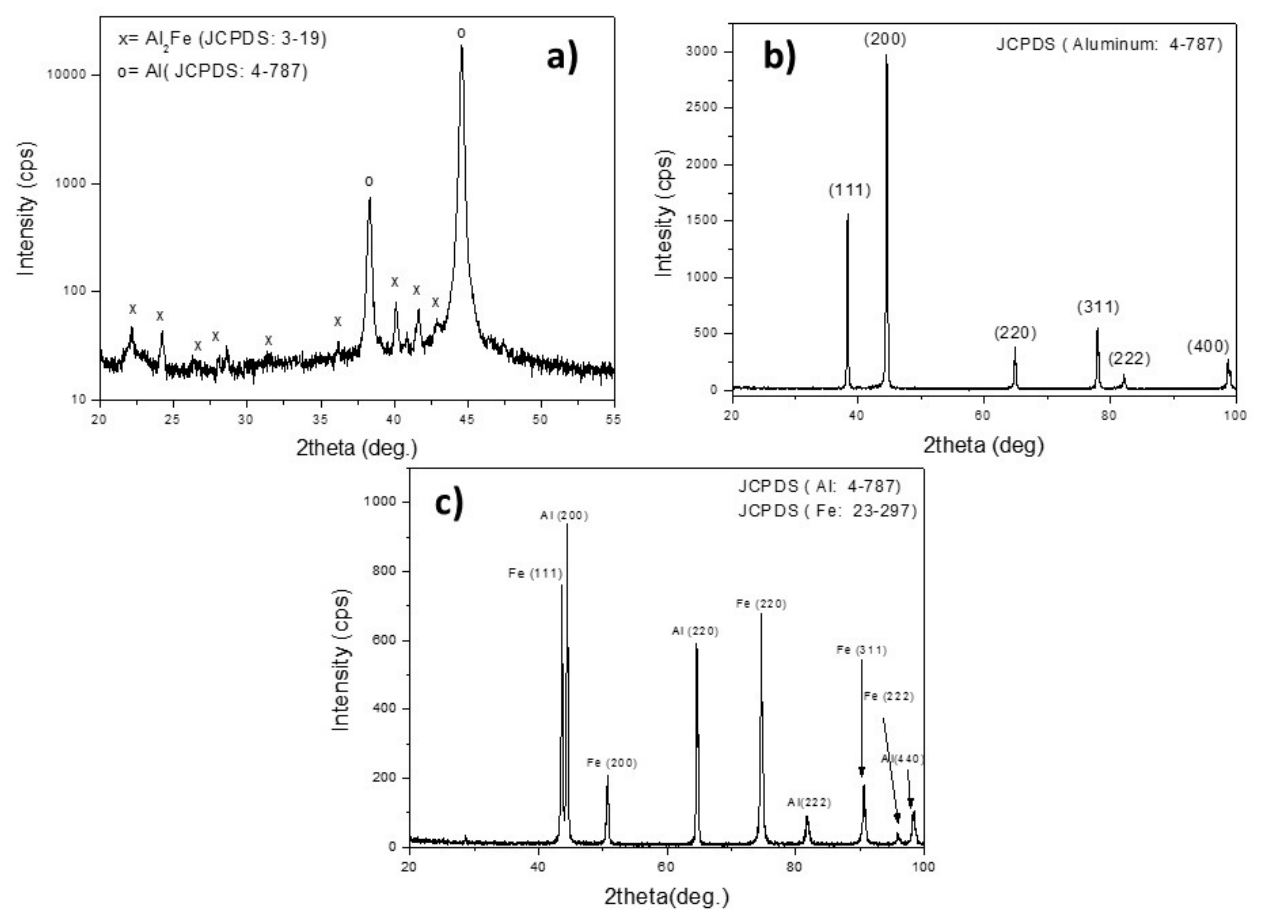

Figure 13. (a) Precision X-ray diffraction analysis in the thinner intermetallic layer. X-ray diffraction analysis in the (b) aluminum and (c) steel fusion zone. 


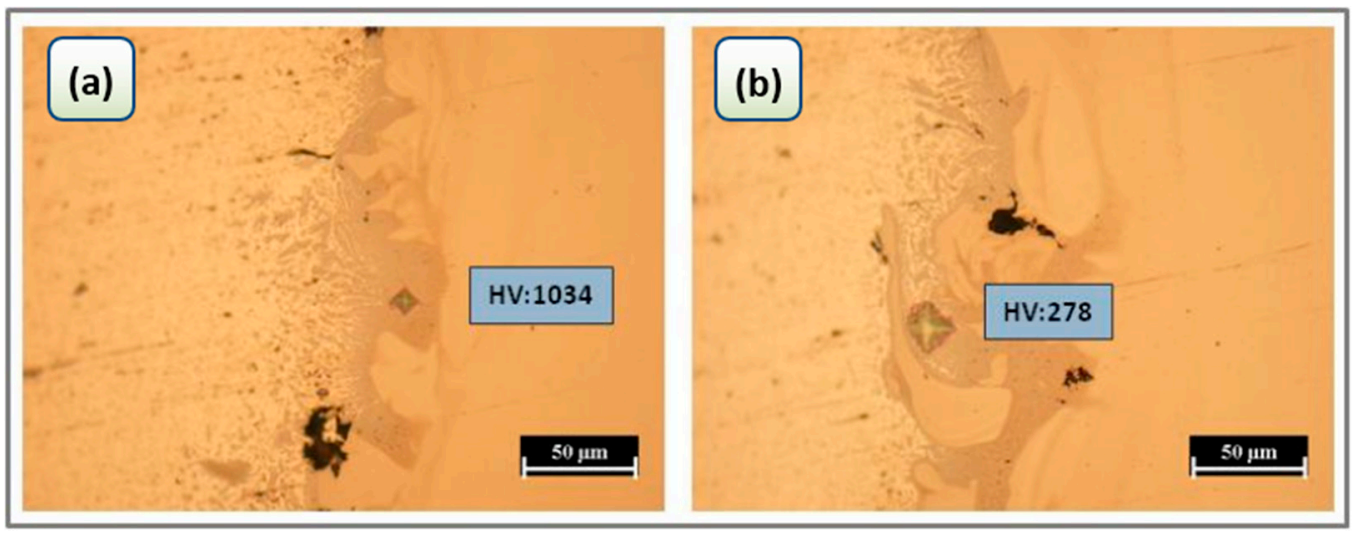

Figure 14. Optical micrographs of joint s1 shows the result of Vickers micro-hardness measurements on the interface aluminum/steel: (a) hardness value due to IMC (b) hardness value due to effects of the IMC and Al matrices.

Figure 15 represents the microhardness at the half thickness of the cross section. The hardness of the Al FZ was higher than that in the heat affected zone (HAZ) and the base material (BM). Rapid solidification, and therefore both grain refining and low grain boundaries' precipitation, increased the hardness in the FZ. The hardness of the Al HAZ was slightly larger than that in the base material. This result may be due to the dissolution of soluble compounds and the consequent strengthening by solid solution. Figure 15 shows that an increase of hardness in the steel was due to grain refinement promoted during the welding process $[43,44]$.

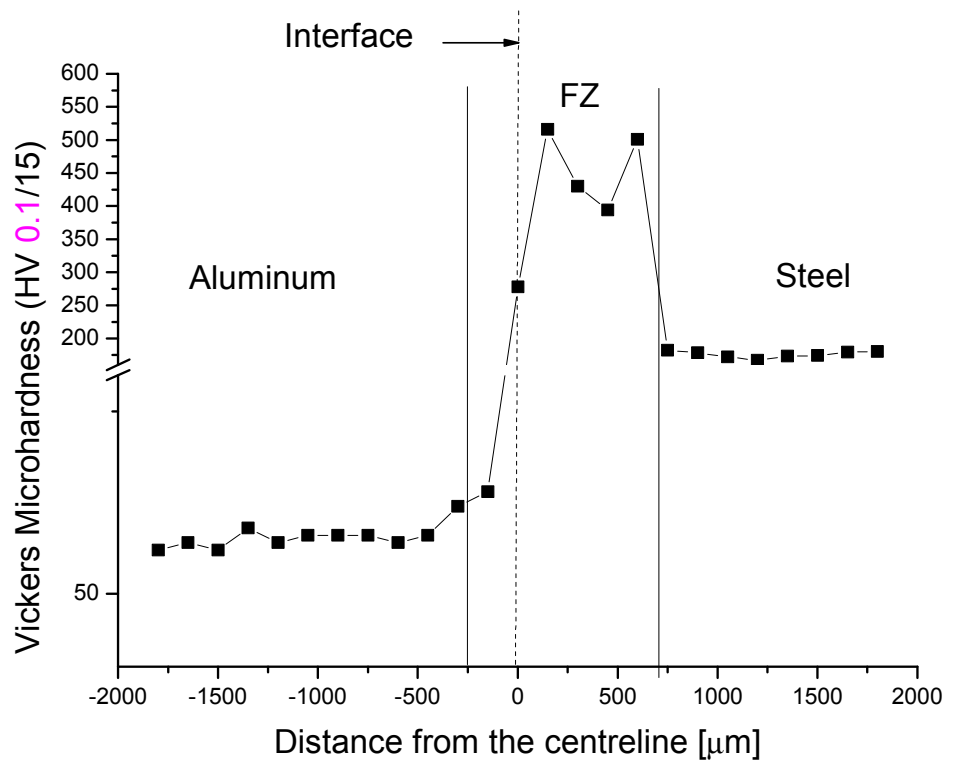

Figure 15. Cross weld section microhardness profile for the laser offset welding.

Microhardness was high in the fusion zone due to the finer grain size (Figure 16) The average size of the grains in the BM steel was $30 \pm 5.7 \mu \mathrm{m}$, meanwhile in the FZ (at both the interface with steel HAZ and Al FZ) it was equal to $6 \pm 1.2 \mu \mathrm{m}$. In the literature, there are several works on the laser welding steel/aluminum which showed an increased hardness due to the refinement of the grain size $[44,45]$. 


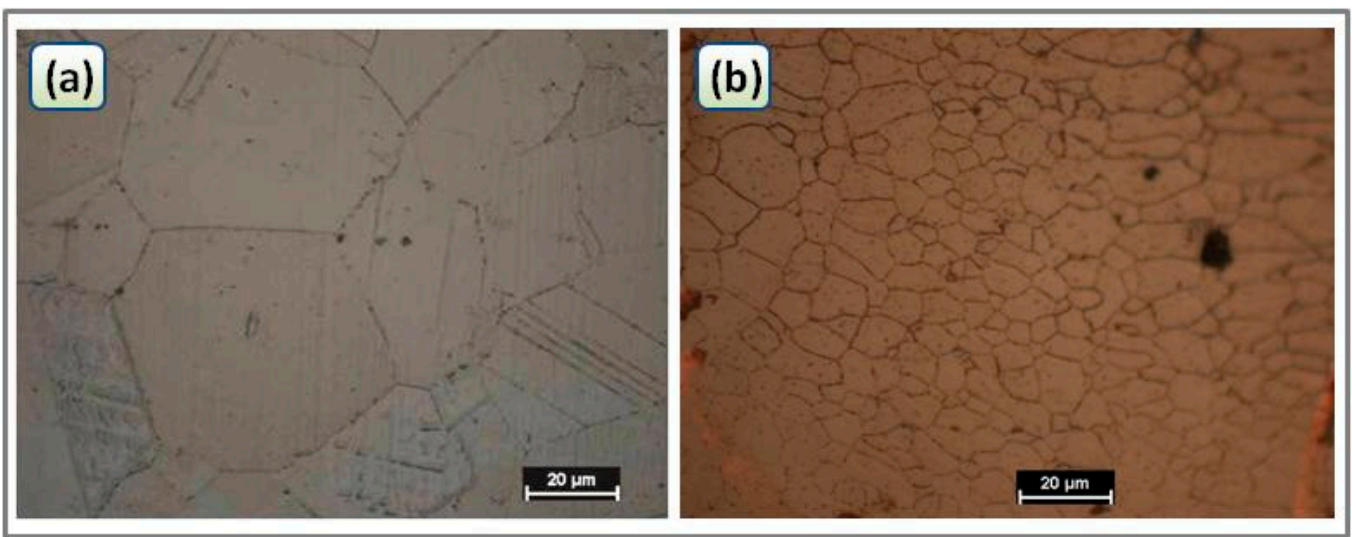

Figure 16. Optical micrographs showing (a) base material of 316L stainless steel and (b) fine structure in the fusion zone due to the fast solidification.

Grain boundary precipitation on the aluminum side did not occur during the joint solidification because of the rapid cooling. If grain boundary precipitation occurred, the hardness of AA5754 would strongly decrease. The precipitation of Al-Mg particles inside the grains leads to softening [27,36].

\section{Laser Hybrid Welding Results}

Figure 17 shows the cross section of the joint produced by hybrid laser-MIG welding. Excessive weld metal was observed at the top surface, while the bottom part presented a slight lack of penetration. The reason why these geometric defects occurred can be explained by assessing the process dynamics. Excessive weld metal resulted from the high wire deposition rate. Lower wire feeding speeds were adopted to enhance the geometric outcome and reduce the defectiveness. Anyhow, reducing the deposition rate of filler metal must correspond to a reduction of the heat input to keep the process energy balance and avoid wire overheating. Then, several experiments were performed with lower values of total power and wire feeding speed. The laser power was kept constant, because it is mainly responsible for penetration. However, even if the laser power was kept constant, the reduction of the MIG power had a detrimental effect on the geometry of the joint, since the amount of total energy was not enough to fully penetrate the sheets' thickness and generate a consistent bond. Thus, the most satisfactory outcome was evaluated for the present analysis (see Table 3). As shown in Figure 17, a good compromise between penetration and excessive weld metal was found. A slight lack of weld penetration was observed at the bottom part (less than $0.3 \mathrm{~mm}$ depth), while the excessive weld metal was limited to $0.6 \mathrm{~mm}$.

As stated above, the stability of the process is dependent on the keyhole dynamics. The balance over different force contribution is needed to sustain the plasma inside the cavity in stable conditions. Either higher pressure of vapor gases or excessive viscous action of liquid walls might lead to keyhole collapse. Since the beam was focused at the interfaces between two dissimilar materials, such a condition was critical for keyhole stability in hybrid welding, which suffered from additional forces gradients. The risk of a collapsing keyhole is less significant in the fiber laser since the absorptivity by metal gas vapors is much less.

However, the significant difference in liquid metal viscosity, thermal properties, and surface tension compromised the process dynamics, leading to the collapse of the keyhole and consequent entrapment of gas bubbles. Because of the rapid contraction of liquid walls and the rapid solidification rate, gas inclusions did not have enough time and energy to escape from the weld pool [46]. Thus, macro voids formed in the fusion zone, and their direction was determined by the viscous metal flows during keyhole collapse.

Because of the significant difference in thermal expansion coefficient between the two metals and the brittleness of IMCs structures, solidification cracks formed at the interface. 
A huge amount of thermal energy was directly provided at the interface between the sheets. Thus, large viscous forces of molten metals were generated. The boundary between the two metals was highly irregular and non-homogeneous. The behavior of the metal at the interface was not governed by controllable thermal gradients. Liquid flows were uncontrolled, since the distribution of viscous forces within the thickness was not scientifically predictable. The hydrodynamic pressure of the molten steel at the top part of the weld had enough energy to penetrate the aluminum substrate (see Figures 17 and 18), while a large volume of liquid aluminum was pulled down by gravity at the bottom side.

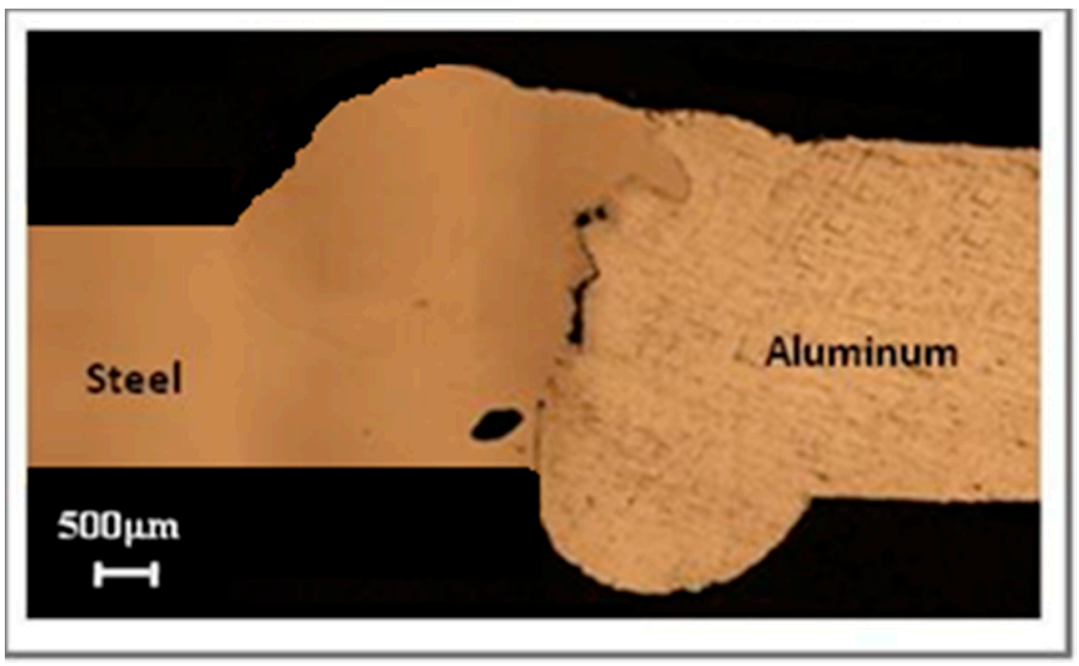

Figure 17. Optical macrograph of cross section by hybrid laser-MIG welding.

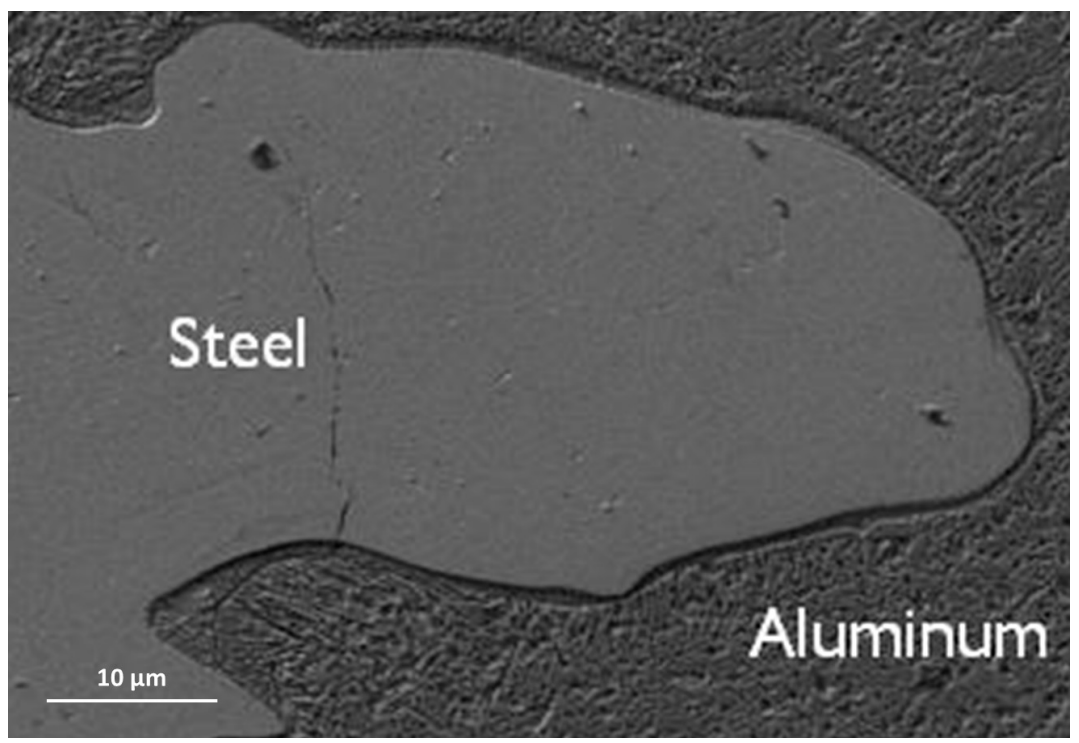

Figure 18. SEM picture showing the highly irregular and non-homogeneous Steel/ Al interface.

The geometry of the IMC layer was inspected by electron microscopy. Figure 19a,b shows that the width exceeded the value of $14 \mu \mathrm{m}$. The process control did not benefit from the hybrid laser-arc combination. The arc promoted a lower cooling rate and non-uniform energy distribution within the thickness. Longer reaction time for IMC growth occurred. As mentioned above, such a result is undesirable for tensile properties [17]. Micro-cracks were detected at both the upper and lower side of the interface. IMC structures at the interface are hugely brittle and no plastic behavior was detected, 
because of the nearly-zero dislocation mobility. During solidification, local stresses exceeded the elastic limit, leading to small fractures both perpendicular and parallel to the layer width.
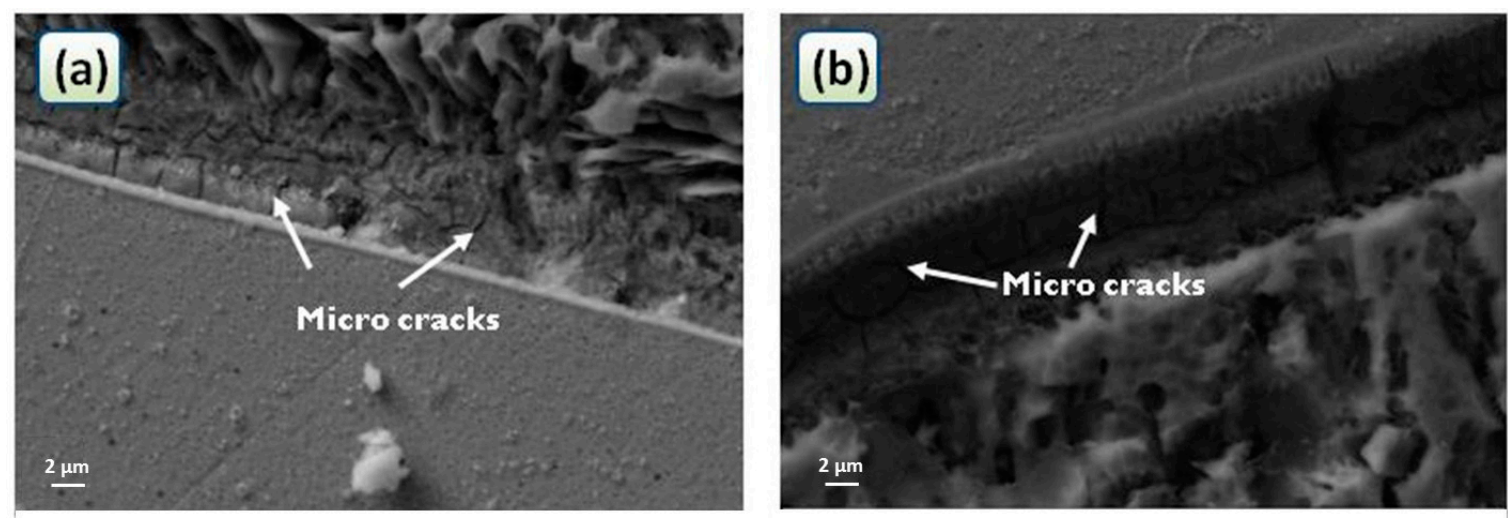

Figure 19. SEM pictures show: (a) Close-up of the upper side of the interface of the sample $(5000 \times)$; (b) Close-up of the lower side of the interface of the sample $(6000 \times)$.

Figure 20 shows the micro-hardness profile detected from the cross section of the sample. Adding arc increased the thermal energy and volume of molten metal compared to single laser welding. Therefore, even if the welding speed was the same as the autogenous laser process, the thermal inertia of the fusion zone was higher and the cooling rate was attenuated, leading to grain size widening and lower hardness values in the FZ.

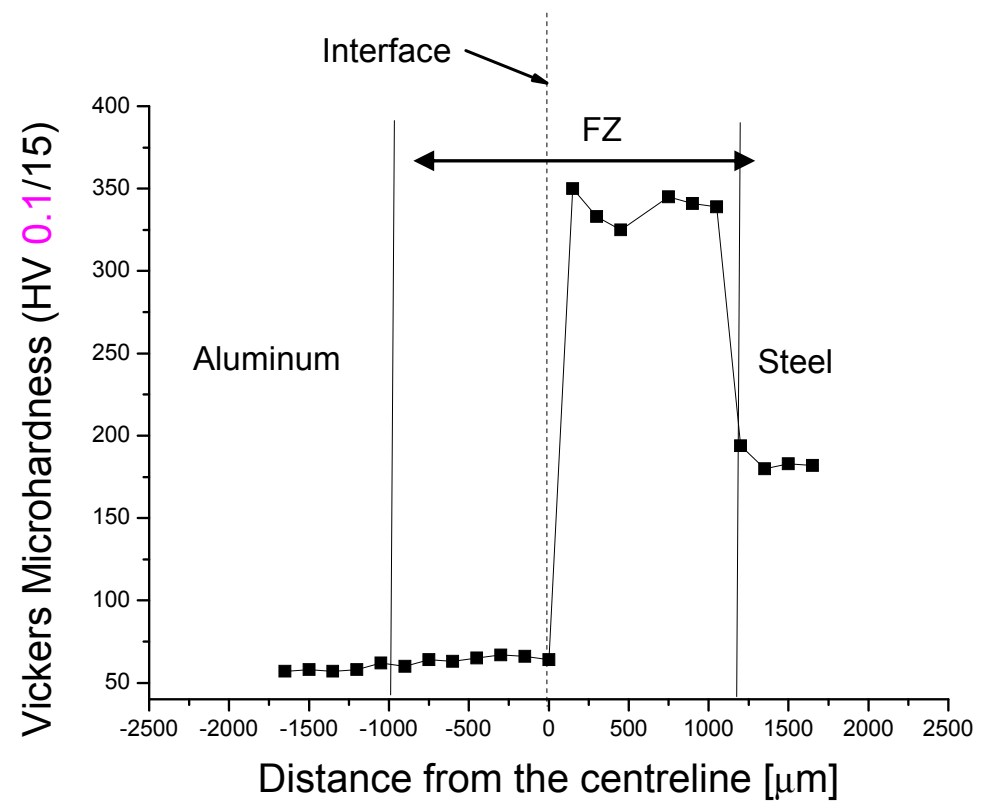

Figure 20. Cross weld section microhardness profile for the hybrid laser-MIG.

The indentation presented in Figure 21 refers to the aluminum/steel interface and reports on a micro-hardness value of 850 Vickers. The IMC area resulted much harder than single-alloy fusion zones and presented a high gradient of thermal expansion coefficient. Therefore, this area is locally subjected to compressive and tensile stresses during the non-uniform solidification, which potentially enables crack propagation. 


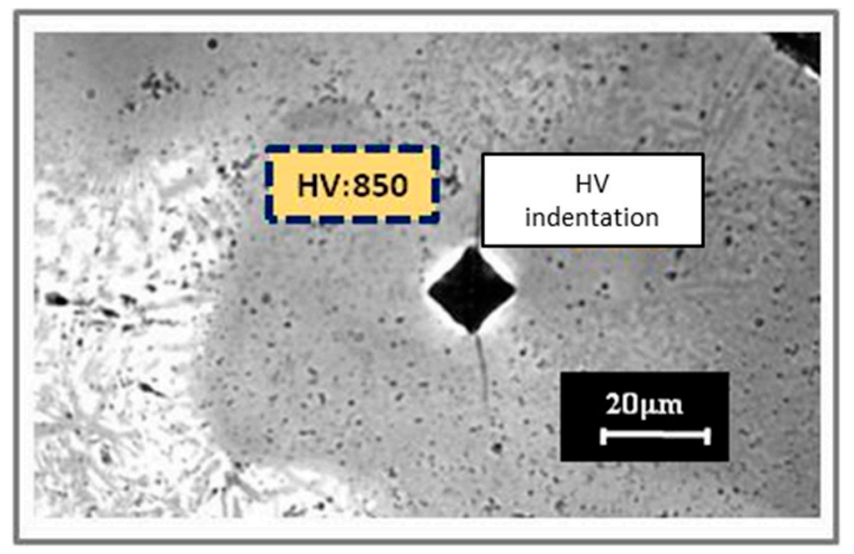

Figure 21. Indentation of the intermetallic layer.

\section{Conclusions}

The present work reported the characterization of the microstructure and the intermetallic compounds (IMCs) in Fe-Al dissimilar welds obtained by fiber off-set and hybrid laser welding. The following considerations were pointed out:

- The EDS/XRD analysis revealed the presence of $\mathrm{FeAl}_{2}$ in the laser welded joint.

- Full penetration and low defectiveness were obtained by laser offset welding. The interaction between liquid phases was restricted. Viscous forces were attenuated by optimizing the process energy balance. Moreover, the high cooling rate and low mix between the two metals enabled IMC layer growth, which was as thick as $6 \mu \mathrm{m}$. As stated in the literature, a thin IMC layer improves the mechanical properties of the weld. Brittle phases were detected but hot cracks were avoided.

- Hybrid laser-arc welding resulted less effective. In fact, an excessive weld crown was observed and the weld presented a lack of penetration. The process was instable because of the significant difference in thermal- and fluid-dynamic properties of the two metals, which compromised the keyhole stability. The interface was highly irregular and non-homogeneous, due to the action of the viscous forces.

It can be concluded that LOW effects on Al-Fe dissimilar metallurgy and IMC can be controlled better than those of the hybrid laser-arc welding. Therefore, further investigation on the weldability of Al-Fe dissimilar welds will focus on the LOW welding technique.

Author Contributions: Giuseppe Casalino and Michelangelo Mortello dealt with the fabrication of the welds, Paola Leo and Patrizias Perulli handled the microstructure analisys and performed the X-ray analysis, Alessandra Varone advised on the interpretation of the X-ray spectra.

Conflicts of Interest: The authors declare no conflict of interest.

\section{References}

1. Yang, J.; Long, L.Y.; Zhang, H. Microstructure and mechanical properties of pulsed laser welded Al/steel dissimilar joint. Trans. Nonferrous Met. Soc. China 2016, 26, 994-1002. [CrossRef]

2. Fridlyander, I.N.; Sister, V.G.; Grushko, O.E.; Berstenev, V.; Sheveleva, L.M.; Ivanova, L.A. Aluminium alloys: Promising materials in the automotive industry. Met. Sci. Heat Treat. 2002, 44, 365-370. [CrossRef]

3. Torkamany, M.J.; Tahamtan, S.; Sabbaghzadeh, J. Dissimilar welding of carbon steel to 5754 aluminum alloy by Nd:YAG pulsed laser. Mater. Des. 2010, 31, 458-465. [CrossRef]

4. Chen, S.; Zhai, Z.; Huang, J.; Zhao, X.; Xiong, J. Interface microstructure and fracture behavior of single/dual-beam laser welded steel-Al dissimilar joint produced with copper interlayer. Int. J. Adv. Manuf. Technol. 2016, 82, 631-643. [CrossRef] 
5. Hiroaki, O.; Schlesinger, M.E.; Mueller, E.M. Alloy Phase Diagrams, 3rd ed.; ASM International: Geauga County, OH, USA, 1992; ISBN 978-1-62708-070-5.

6. Çam, G.; Erim, S.; Yeni, Ç.; Koçak, M. Determination of mechanical and fracture properties of laser beam welded steel joints. Weld. J. 1999, 78, 193-201.

7. Çam, G.; Yeni, Ç.; Erim, S.; Ventzke, V.; Koçak, M. Investigation into properties of laser welded similar and dissimilar steel joints. Sci. Technol. Weld. Join. 1998, 3, 177-189. [CrossRef]

8. Mvola, B.; Kah, P.; Martikainen, J.; Suoranta, R. Dissimilar high-strength steels: Fusion welded joints, mismatches, and challenges. Rev. Adv. Mater. Sci. 2016, 44, 146-159.

9. Liu, X.; Lan, S.; Ni, J. Analysis of process parameters effects on friction stir welding of dissimilar aluminum alloy to advanced high strength steel. Mater. Des. 2014, 59, 50-62. [CrossRef]

10. Movahedi, M.; Kokabi, A.H.; Reihani, S.S.; Cheng, W.-J.; Wang, C.J. Effect of annealing treatment on joint strength of aluminum/steel friction stir lap weld. Mater. Des. 2013, 44, 487-492. [CrossRef]

11. Habibnia, M.; Shakeri, M.; Nourouzi, S.; Givi, M.B. Microstructural and mechanical properties of friction stir welded $5050 \mathrm{Al}$ alloy and 304 stainless steel plates. Int. J. Adv. Manuf. Technol. 2015, 76, 819-829. [CrossRef]

12. Sahin, M. Joining of stainless-steel and aluminium materials by friction welding. Int. J. Adv. Manuf. Technol. 2009, 41, 487-497. [CrossRef]

13. Campanelli, S.L.; Casalino, G.; Casavola, C.; Moramarco, V. Analysis and comparison of friction stir welding and laser assisted friction stir welding of aluminum alloy. Materials 2013, 6, 5923-5941. [CrossRef]

14. Ratanathavorn, W.; Melander, A.; Magnusson, H. Intermetallic compounds in friction stirred lap joints between AA5754/galvanised ultra-high strength steel. Sci. Technol. Weld. Join. 2016, 21, 653-659. [CrossRef]

15. Oikawa, H.; Ohimiya, S.; Yoshimura, T.; Saitoh, T. Resistance spot welding of steel and aluminum sheet using insert metal sheet. Sci. Technol. Weld. Join. 1999, 4, 80-88. [CrossRef]

16. Qin, G.; Su, Y.H.; Meng, X.M.; Fu, B.L. Numerical simulation on MIG arc brazing-fusion welding of aluminum alloy to galvanized steel plate. Int. J. Adv. Manuf. Technol. 2015, 78, 1917-1925. [CrossRef]

17. Gao, M.; Chen, C.; Mei, S.W.; Wang, L.; Zeng, X.Y. Parameter optimization and mechanism of laser-arc hybrid welding of dissimilar Al alloy and stainless steel. Int. J. Adv. Manuf. Technol. 2014, 74, 199-208. [CrossRef]

18. Çam, G. Friction stir welded structural materials: Beyond $\mathrm{Al}$ alloys. Int. Mater. Rev. 2011, 56, 1-48. [CrossRef]

19. Chen, S.; Huang, J.; Ma, K.; Zhang, H.; Zhao, X. Influence of a Ni-foil interlayer on Fe/Al dissimilar joint by laser penetration welding. Mater. Lett. 2012, 79, 296-299. [CrossRef]

20. Mathieu, A.; Pontevicci, S.; Viala, J.; Cicala, E.; Matteï, S.; Grevey, D. Laser brazing of a steel/aluminum assembly with hot filler wire (88\% Al, 12\% Si). Mater. Sci. Eng. A 2006, 435, 19-28. [CrossRef]

21. Dharmendra, C.; Rao, K.; Wilden, J.; Reich, S. Study on laser welding-brazing of zinc coated steel to aluminum alloy with a zinc based filler. Mater. Sci. Eng. 2011, 528, 1497-1503. [CrossRef]

22. Song, J.; Lin, S.; Yang, C.; Ma, G.; Liu, H. Spreading behavior and microstructure characteristics of dissimilar metals TIG welding brazing of aluminum alloy to stainless steel. Mater. Sci. Eng. 2009, 509, 31-40. [CrossRef]

23. Choi, C.; Kim, D.; Nam, D.; Kim, Y.; Park, Y. A hybrid joining technology for aluminum/zinc coated steels in vehicles. J. Mater. Sci. Technol. 2010, 26, 858-864. [CrossRef]

24. Zhang, K.; Zhenglong, L.; Chen, Y.; Liu, M.; Liu, Y. Microstructure characteristics and mechanical properties of laser-TIG hybrid welded dissimilar joints of Ti-22Al-27Nb and TA15. Opt. Laser Technol. 2015, 73, 139-145. [CrossRef]

25. Thomy, C.; Vollertsen, F. Laser-Mig Hybrid Welding of Aluminium to Steel Effect of Process Parameters on Joint Properties. Weld. World 2012, 56, 124-132. [CrossRef]

26. Leo, P.; Renna, G.; Casalino, G.; Olabi, A.G. Effect of power distribution on the weld quality during hybrid laser welding of an Al-Mg alloy. Opt. Laser Technol. 2015, 73, 118-126. [CrossRef]

27. Casalino, G.; Campanelli, S.L.; Ludovico, A.D. Laser-arc hybrid welding of wrought to selective laser molten stainless steel. Int. J. Adv. Manuf. Technol. 2013, 68, 209-216. [CrossRef]

28. Zeng, Z.; Li, X.; Miao, Y.; Wu, G.; Zhao, Z. Numerical and experiment analysis of residual stress on magnesium alloy and steel butt joint by hybrid laser-TIG welding. Comput. Mater. Sci. 2011, 50, 1763-1769. [CrossRef]

29. Casalino, G.; Mortello, M.; Peyre, P. Yb-YAG laser offset welding of AA5754 and T40 butt joint. J. Mater. Process. Technol. 2015, 223, 139-149. [CrossRef] 
30. Rathod, M.J.; Kustuna, M. Joining of aluminum alloy 5052 and low carbon steel by laser roll welding. Weld. J. Res. Suppl. 2004, 83, 16-26.

31. Casalino, G.; Mortello, M. Modeling and experimental analysis of fiber laser offset welding of Al-Ti butt joints. Int. J. Adv. Manuf. Technol. 2016, 83, 89-98. [CrossRef]

32. Casalino, G.; Guglielmi, P.; Lorusso, V.D.; Mortello, M.; Peyre, P.; Sorgente, D. Laser offset welding of AZ31B magnesium alloy to 316 stainless steel. J. Mater. Process. Technol. 2017, 242, 49-59. [CrossRef]

33. Miranda, R.M.; Assunção, E.; Silva, R.J.C.; Oliveira, J.P.; Quintino, L. Fiber laser welding of NiTi to Ti-6Al-4V. Int. J. Adv. Manuf. Technol. 2015, 81, 1533-1538. [CrossRef]

34. Pardal, G.; Meco, S.; Ganguly, S.; Williams, S.; Prangnell, P. Dissimilar metal laser spot joining of steel to aluminium in conduction mode. Int. J. Adv. Manuf. Technol. 2014, 73, 365-373. [CrossRef]

35. Kumar, S.; Nadendla, H.B.; Scamans, G.M.; Eskin, D.G.; Fan, Z. Solidification behavior of an AA5754 alloy ingot cast with high impurity content. Int. J. Mater. Res. 2012, 103, 1228-1234. [CrossRef]

36. Smith, W.F. Structure and Properties of Engineering Alloys, 1st ed.; McGraw-Hill: New York, NY, USA, 1992; pp. 186-191. ISBN 0-07-59172-5.

37. Davis, J.R. Aluminum and Aluminum Alloys, 1st ed.; ASM International: Geauga County, OH, USA, 1993; ISBN 978-0-87170-496-2.

38. Miao, Y.G.; Han, D.F.; Yao, J.Z.; Li, F. Microstructure and interface characteristics of laser penetration brazed magnesium alloy and steel. Sci. Technol. Weld. Join. 2010, 15, 97-103. [CrossRef]

39. Kobayashi, S.; Yakou, T. Control of intermetallic compound layers at interface between steel and aluminum by diffusion-treatment. Mater. Sci. Eng. A 2002, 338, 44-53. [CrossRef]

40. Sun, J.; Yan, Q.; Gao, W.; Huang, J. Investigation of laser welding on butt joints of Al/steel dissimilar materials. Mater. Des. 2015, 83, 120-128. [CrossRef]

41. Qiu, R.; Shi, H.; Zhang, K.; Tu, Y.; Iwamotoc, C.; Satonaka, S. Interfacial characterization of joint between mild steel and aluminum alloy welded by resistance spot welding. Mater. Charact. 2010, 61, 684-688. [CrossRef]

42. Messler, R.W. Principles of Welding: Processes, Physics, Chemistry, and Metallurgy, 1st ed.; Wiley-VCH: New York, NY, USA, 2007; pp. 406-423. ISBN 0-471-25376-6.

43. Brooks, J.; Lippold, J. Welding, Brazing, and Soldering, 1st ed.; ASM International: Geauga County, OH, USA, 1993; ISBN 978-0-87170-382-8.

44. Kumar, N.; Mukherjee, M.; Bandyopadhyay, A. Comparative study of pulsed Nd:YAG laser welding of AISI 304 and AISI 316 stainless steels. Opt. Laser Technol. 2017, 88, 24-39. [CrossRef]

45. Sathiya, P.; Mishra, M.K.; Shanmugarajan, B. Effect of shielding gases on microstructure and mechanical properties of super austenitic stainless steel by hybrid welding. Mater. Des. 2012, 33, 203-212. [CrossRef]

46. Cao, X.; Wallace, W.; Immarigeon, J.P.; Poon, C. Research and Progress in Laser Welding of Wrought Aluminum Alloys. II. Metallurgical Microstructures, Defects, and Mechanical Properties. Mater. Manuf. Process. 2003, 18, 23-49. [CrossRef]

(C) 2017 by the authors. Licensee MDPI, Basel, Switzerland. This article is an open access article distributed under the terms and conditions of the Creative Commons Attribution (CC BY) license (http:/ / creativecommons.org/licenses/by/4.0/). 